\title{
Homemade Products and Socio-Cultural Values of Wheat Seed Production in Ambo and Dandi Districts of West Central Ethiopia
}

\author{
Negash Geleta $^{1^{*}}$ and Heinrich Grausgruber ${ }^{2}$ \\ ${ }^{1}$ Department of Plant Sciences, College of Agriculture and Natural resources, Wollega University, \\ P.O Box No: 395 Nekemte, Ethiopia
}

${ }^{2}$ Department of Applied Plant Sciences and Plant Biotechnology, Institute of Agronomy and Plant Breeding, BOKU- University of Natural Resources and Applied Life Sciences, Vienna, Austria, A-1180

\begin{tabular}{|c|c|}
\hline Abstract & Article Information \\
\hline $\begin{array}{l}\text { The objective of the study was to document homemade dishes/beverages from wheat } \\
\text { landraces and socio-cultural lifestyles of people related to wheat production in Ambo and } \\
\text { Dandi Districts, West Shewa. A total of four Peasant Associations (PAs) (Awaro, Gosu-Kora, } \\
\text { Awash-Bole and Haro-Dule) were purposively selected from the two districts. A questionnaire } \\
\text { on wheat seed systems, utilization and socio-cultural life style of people related to wheat } \\
\text { landraces cultivation and conservation were developed. Focused group discussions were } \\
\text { made at village level among groups of farmers on specific points led by the principal } \\
\text { researchers. Emphasis was given to women since the utilization of crops in the households } \\
\text { are usually their responsibilities. In addition, a total of } 90 \text { households were interviewed } \\
\text { following the questionnaire developed on the three themes. Finally consolidated ideas were } \\
\text { noted by the researchers and organized into tables and figures of proportions. Farmers } \\
\text { reported that nine different homemade dishes/snacks and two beverages which can be made } \\
\text { from wheat landraces. These include dufo-dabo, budena/injera, ambasha/kita, kinche, marka, } \\
\text { mullu, aka'i, dabo-kolo, biscuit and beverages farso and arake. The different wheat landraces } \\
\text { are suited for the preparation of at least two or more different dishes/snacks and beverages. } \\
\text { These different dishes/snacks and beverages are prepared at regular times or on special } \\
\text { occasions (e.g. New Year, religious and non-religious social gatherings). Some of the dishes } \\
\text { and beverages are used as sources of income by urban and suburban women who sell their } \\
\text { products at markets or bus stops. Seed colour plays a critical role in determining end use } \\
\text { qualities. White seed varieties are preferred for food uses while the purple seed types are used } \\
\text { for beverage production. The people of the study areas have deep rooted culture connected to } \\
\text { wheat production. Farmers use folksongs and proverbs to express the end use qualities and } \\
\text { their peculiar morpho-agronomic characteristics of different wheat landrace varieties. }\end{array}$ & $\begin{array}{l}\text { Article History: } \\
\text { Received : 16-09-2013 } \\
\text { Revised : 07-11-2013 } \\
\text { Accepted : 10-11-2013 } \\
\text { Keywords: } \\
\text { Ambo } \\
\text { Dandi } \\
\text { End uses } \\
\text { Ethiopia } \\
\text { Folksong } \\
\text { Tetraploid wheats } \\
\text { *Corresponding Author: } \\
\text { Negash Geleta } \\
\text { E-mail: } \\
\text { ayananegash@yahoo.com }\end{array}$ \\
\hline
\end{tabular}

\section{INTRODUCTION}

Wheat (Triticum sp.) is one of the major cereals grown in the mid to high altitude zones and it is commonly grown in Ambo and Dandi districts, west central highlands of Ethiopia (CSA, 2012; Geleta and Grausgruber, 2012; Geleta and Grausgruber, 2013a,b). Different wheat species are cultivated in Ethiopia: T. aestivum, T. turgidum, T. durum, T. polonicum, T. carthlicum, T. atheopicum, and T. dicoccum (Eticha et al., 2005; Eticha et al., 2006). The different wheat types are grown for special purposes or end use products. End use qualities of different varieties of crops and socio-cultural life styles of farming communities influence the survival and/or conservation of landraces. Shewayrga and Sopade (2011) reported the influence of end use qualities of different landraces of barley (Hordeum vulagare L.) on maintenance and diversity on-farm in Northern Eastern Ethiopia Highlands.

Diverse food types are the results of different landraces of different food crops which contain different end use qualities (Asfaw, 2000; Tsegaye and Berg, 2007b; Eticha et al., 2009; Geleta et al., 2009; Shewayrga and Sopade, 2011). Tsegaye and Berg (2007b) reported 14 different homemade dishes from tetraploid wheats in East Shewa, central Ethiopia while Eticha et al. (2009) reported 17 different homemade dishes of barley (Hordeum vulgare) landraces in West Shewa, central Ethiopia; and Shewayrga and Sopade (2011) reported more than 20 types of homemade dishes and beverages which can be prepared from different barley landraces in North Eastern Ethiopia highlands. 


\section{Negash Gelata and Heinrich Grausgruber}

Farmers grow different varieties of the same crop in the same plot of land to maximize end uses and minimize risks of crop failure due to pests and diseases, drought, and other hazards. For instance, in Welo, Northern Ethiopia, farmers grow different varieties of sorghum for different end uses, e.g. the variety Ganseber which means 'pot breaker' because it makes such a good beer and is also used for making bread comparable in quality to wheat bread (Grain, 2007); While in west central Ethiopia, farmers grow and maintain Qamadi-Dima (a tetraploid wheat landrace variety) for its high brewing quality (beer and alcholic liquor) (Geleta and Grausgruner, 2013a). In central highlands (south Welo and North Shewa) of Ethiopia, cereal based mixed cropping systems such as sorghum/tef intercropped and boarder cropped with different oil crops such as noog (Guizotia abyssinica), sesame (Sesamum indicum), linseed (Linum usitatissimum), safflower (Carthamus tinctorius), Ethiopian mustard (Brassica carinata) and sunflower (Helianthus annus) are the main practices for existences of diversity in crop varieties in the system and farmers do such practices to maximize total land equivalent ratio and minimize the risk of crops failure (Geleta et al., 2002). In rural areas of Ethiopia, barley (Hordeum vulgare L.) is known for medicinal values (Eticha et al., 2009; Eticha et al., 2010).

Besides qualities of different wheat landrace varieties for different end uses, the socio-cultural life styles of people might influence the utilization and conservation of landraces. According to Rana et al. (2007) there is a positive relationship between resources endowed farmers and the conservation of rice landraces which are vulnerable to genetic erosion and those landraces with socio-cultural and market preferred traits are few in number in Nepal. Therefore, the objectives of the study were to document the homemade products of wheat landraces and the socio-cultural life style of people related to wheat seed production in Ambo and Dandi districts, West Shewa, Ethiopia.

\section{MATERIALS AND METHODS}

\section{Study Site}

The study was carried out in Ambo and Dandi districts, West Shewa, Ethiopia. Two Peasant Associations (PAs) (Awaro and Gosu-Kora) and two Peasant Associations (Awash-Bole and Haro-Dule) in Ambo and Dandi district, respectively were purposively selected for the study from August to October 2008 (see detail study site characteristics in: Geleta and Grausgruber, 2013a).

\section{Methods of Data Collection}

A questionnaire on seed systems, utilization and socio-cultural life style of people related to wheat landrace cultivation and conservation were developed by the researchers. Personnel from the Agricultural Development Offices of both districts together with the principal investigators approached wheat growing farmers. Three to five groups were formed per peasant association. Focussed group discussions were held at village level among groups of farmers. Every farmer from the group was allowed to give his/her ideas freely. During the group discussion specific points were raised by the principal researchers following the questionnaire. Proportionally women and men were participated in group discussions. Emphasis was given more to women since the utilization of crops in the households are usually their
Sci. Technol. Arts Res. J., Oct-Dec 2013, 2(4): 62-70

responsibilities. Women in rural Ethiopia are responsible for indoor activities like preparation of foods, gathering fuel wood, looking after children, etc. whereas men are responsible for ploughing the land, for raising crops, keeping cattle, etc. Weeding, harvesting and threshing of crops are done both by men and women. In addition a total of 90 households were interviewed following the questionnaire developed on the three themes. Finally, consolidated ideas were noted by the researcher.

\section{Data Analysis}

The qualitative data obtained from the group discussions were organised based on the theme of the questionnaire: seed systems, end uses, and sociocultural values of wheat production. Frequency distributions of households using the different systems were computed using the Sigmaplot software and the qualitative data were also presented into different tables and graphics of proportions.

\section{RESULTS}

\section{Seed Sources for Wheat Landraces and Improved Varieties}

The major seed sources for wheat landraces and improved varieties are presented in Table 1. Farmers obtain wheat landrace seeds either through exchange with other commodities among neighbours or purchase it from the market. Besides, farm saved seeds are also a practice among farmers of Awaro (Ambo district). The major seed sources of improved wheat varieties for the farmers of the areas are the MoA (Ministry of Agriculture/through extension services) and/or private seed companies. Seeds of improved varieties are also obtained through purchasing from the market and/or seed exchanges with other commodities among neighbours.

\section{Seed Selection}

In the study areas farmers practice seed selection for both landraces and improved varieties (Table 2). Seed selection is done mainly at planting and at harvesting. These practices enable the farmers to keep the seeds free of weed seeds and other inert materials. Farmers also select for healthy plants with good spikes. Although the farmers select seeds for purity, they allow in most cases mixtures of two or more varieties/landraces. The reasons are unclear but it is assumed that thereby the farmers avoid the risk of crop failures due to unfavourable environmental conditions, diseases and pests and, moreover, add diversity to their diet (Bekele, 1984).

\section{Grain Storage System}

The major storage systems used by the farmers are presented in Figures 1 and 2. The major grain storage structures are Gumbi, Gagura (traditional beehive) and Qalqalo (animal skin such as goat and sheep prepared as sack). Gotara and Gani (clay pot) are less frequently used. Usually seeds for planting are stored in sacks. Gumbi is made of mud, cow dung and straw of crop residue such as tef and with a layered structure of rings staked one over the other. Gotara is made of bamboo tree and its inside wall is plastered with cow dung or mud. Grain for the market is temporarily stored in sacks or in some cases in Gumbi, while grain for consumption is primarily stored in Gumbi and also in sacks or Gotara. 
Table 1: Proportion of households using different seed sources of wheat landraces and improved varieties for planting in Ambo and Dandi districts.

\begin{tabular}{|c|c|c|c|c|}
\hline \multirow[b]{2}{*}{ Seed Sources } & \multicolumn{2}{|c|}{ Ambo } & \multicolumn{2}{|c|}{ Dandi } \\
\hline & $\begin{array}{c}\text { Gosu-Kora } \\
\text { Peasant } \\
\text { Association } \\
(n=17)\end{array}$ & $\begin{array}{c}\text { Awaro } \\
\text { Peasant } \\
\text { Association } \\
(n=18)\end{array}$ & $\begin{array}{l}\text { Awash-Bole } \\
\text { Peasant } \\
\text { Association } \\
(n=25)\end{array}$ & $\begin{array}{c}\text { Haro-Dule } \\
\text { Peasant } \\
\text { Association } \\
(n=30)\end{array}$ \\
\hline \multicolumn{5}{|l|}{ Landraces } \\
\hline Neighbour & 89 & 50 & 80 & 93 \\
\hline Market & 94 & 89 & 84 & 90 \\
\hline Farm saved & 19 & 83 & 20 & 7 \\
\hline \multicolumn{5}{|l|}{ Improved Varieties } \\
\hline Neighbour & 31 & 11 & 36 & 23 \\
\hline Market & 38 & 44 & 4 & - \\
\hline Relatives & 6 & - & 16 & 3 \\
\hline Farm saved & 6 & - & - & - \\
\hline MoA/Extension service & 94 & 78 & 88 & 90 \\
\hline Seed multiplying farmer & - & - & 4 & - \\
\hline NGO & - & - & 4 & - \\
\hline
\end{tabular}

Table 2: Proportion of households using different seed selection time of wheat landraces and improved varieties in of Ambo and Dandi districts.

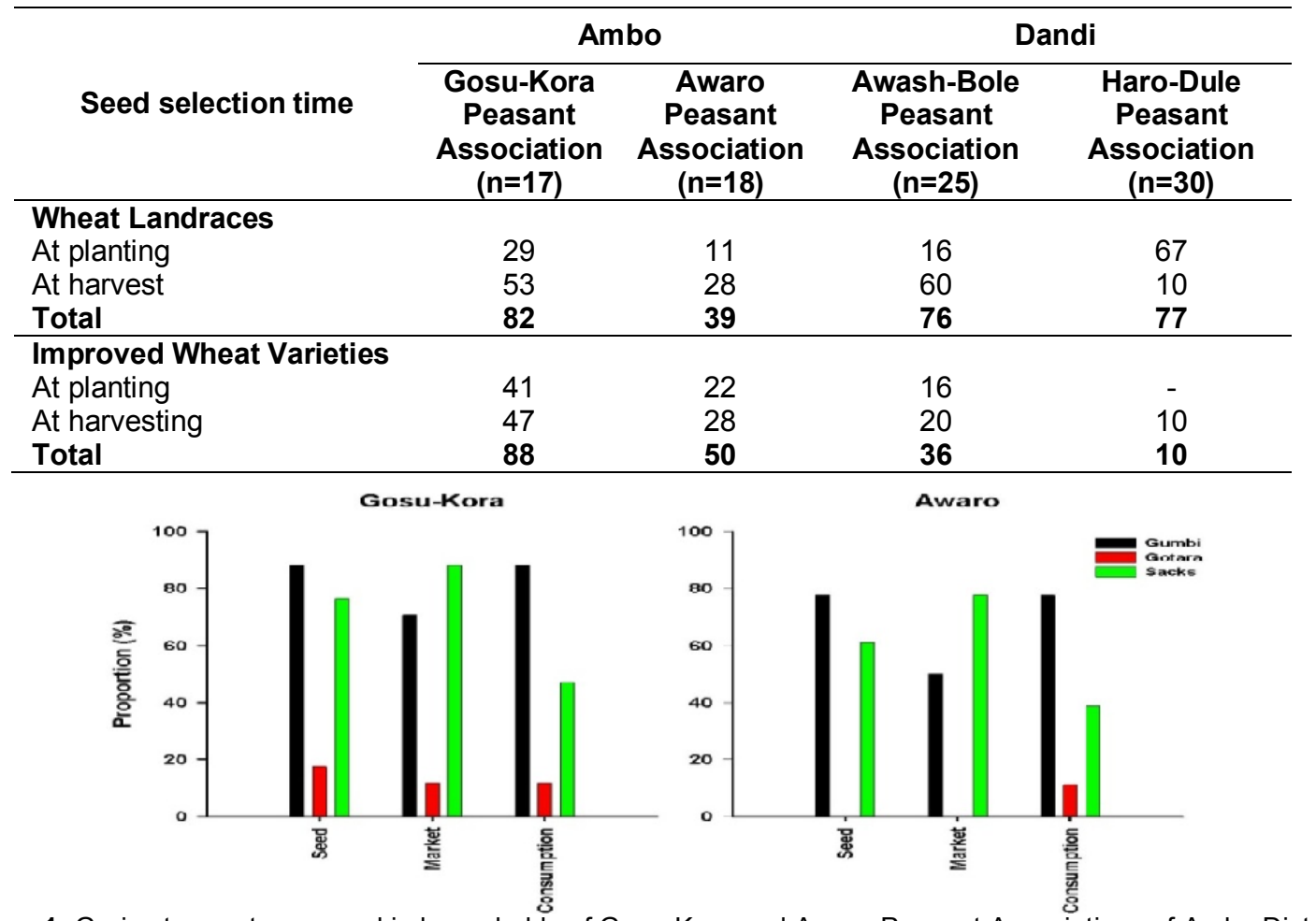

Figure 1: Grain storage types used in households of Gosu-Kora and Awaro Peasant Associations of Ambo District.
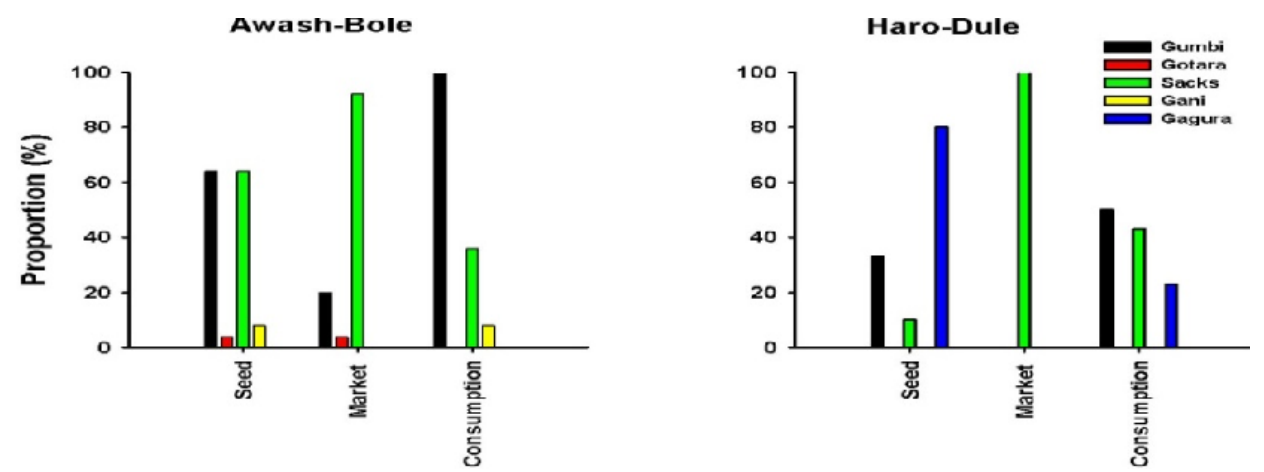

Figure 2: Grain storage types used in households of Awash-Bole and Haro-Dule Peasant Associations of Dandi District. 


\section{Negash Gelata and Heinrich Grausgruber}

The type of storage structures depend on the type of grain. If the grain is only for temporal storage, e.g. for sale at the market and seed for next planting, it is stored in either sacks or Gagura. The difference between seed for planting and grain for sale is that the former is stored in clean containers and in some cases is treated with pesticides. If the grain is used for household consumption, it is mainly stored in Gumbi, which is cheap, and relatively longer life span. It can be used up to five years since from establishment. Gotara is among nowadays seldom used by the farmers of the study areas. Once established it can be used up to 10 and more years, however, compared to the other storage systems it is much more expensive to get materials for construction.
Sci. Technol. Arts Res. J., Oct-Dec 2013, 2(4): 62-70

\section{Homemade Foods, Snacks and Drinks}

Farmers reported that nine different homemade dishes/snacks and two beverages made from wheat landraces in Ambo and Dandi districts (Table 3). These include types of bread (Dufo-dabo, Budena/Injera, Ambasha/Kita), types of porridge (Kinche and Marka), boiled grains (Mullu), roasted whole grains (Aka'), Dabokolo, biscuits and beverages (Farso and Arake). These foods and drinks are prepared either regularly or on different occasions based on cultural settings and beliefs (Table 4). In the latter case the products are used for ritual purposes.

Table 3: Tetraploid wheat landraces and their end uses.

\begin{tabular}{|c|c|c|}
\hline Landrace & Grain colour & Homemade products \\
\hline Asnaka & purple & Snack (aka'i, mullu), beverage (farso, arake and bikil) \\
\hline Golli-Hinga'u & white & $\begin{array}{l}\text { Bread (budena, dufo-dabo, ambasha), porridge (marka) and } \\
\text { snack (mullu and aka'i) }\end{array}$ \\
\hline Kamadi-Dima & purple & Beverages (farso, arake, bikil) and bread (budena) \\
\hline Biranu & white & $\begin{array}{l}\text { Bread (dufo-dabo, budena, and ambasha) and snack (mullu, } \\
\text { aka'i) and porridge (marka) }\end{array}$ \\
\hline Biraye & purple & Beverage (farso, arake, and bikil) and bread (budena) \\
\hline Kenya & white & $\begin{array}{l}\text { Beverage (farso, and arake), bread (dufo-dabo, budena), snack } \\
\text { (mullu, and aka'i) and porridge (marka, and Kinche) }\end{array}$ \\
\hline Bataja / Butuji & white & $\begin{array}{l}\text { Bread (dufo-dabo, ambasha, and budena), snack (mullu, aka'i) } \\
\text { and porridge (marka) }\end{array}$ \\
\hline Kaffelli & white / red & Bread (dufo-dabo, ambasha and budena) and porridge (marka) \\
\hline Barsadadi & white & $\begin{array}{l}\text { Beverage (farso, arake), bread (dufo-dabo and budena) and } \\
\text { snack (aka'i and mullu) }\end{array}$ \\
\hline Galane & white & $\begin{array}{l}\text { Bread (dufo-dabo and budena), snack (aka'i and mullu) and } \\
\text { porridge (kinche) }\end{array}$ \\
\hline Boroka & white & Bread (dufo-dabo and budena) \\
\hline Hayibo & white & $\begin{array}{l}\text { Bread (dufo-dabo, budena and ambasha), porridge (marka) and } \\
\text { snack (mullu and aka'i) }\end{array}$ \\
\hline Badag / Shalu & purple / black & Beverage (farso, arake and bikil), and bread (budena) \\
\hline Magal-Sala & white & $\begin{array}{l}\text { Beverage (farso and arake), porridge (kinche) and bread (dufo- } \\
\text { dabo and ambasha) }\end{array}$ \\
\hline Gofari & white & $\begin{array}{l}\text { Beverage (farso and arake), bread (dufo-dabo) and snack (aka'i } \\
\text { and mullu) }\end{array}$ \\
\hline Lucha & purple & Beverage (farso, arake and bikil) and porridge (kinche) \\
\hline Boyido & red & $\begin{array}{l}\text { Bread (dufo-dabo, ambasha, and budena) and beverage (farso } \\
\text { and arake) }\end{array}$ \\
\hline Fitale (dalati) & white & \\
\hline
\end{tabular}

Table 4: Traits of wheat landraces required for the processing of traditional foods and beverages in Ambo and Dandi districts

\begin{tabular}{ll}
\hline Food / beverage types & Grain trait quality preference \\
\hline Bread types & White seed colour; large seed size preferred \\
$\begin{array}{l}\text { Dufo-dabo } \\
\text { Budena/injera }\end{array}$ & $\begin{array}{l}\text { All types but white seed colour is preferred } \\
\text { White grain colour is preferred }\end{array}$ \\
\hline Pmbasha/kita & \\
Maridge types & All seed colours but white is preferred \\
kinche & Vitreous seeds; large seed size \\
\hline Boiled and roasted grains types & \\
Aka'i (roasted grain) & All types \\
Mullu (boiled grain) & All types \\
\hline Malt and beverages types & \\
Bikil (malt) & Purple seed colour preferred \\
Farso (local beer) & Purple seed colour preferred \\
\hline Arake (local liquor) & Purple seed colour preferred \\
\hline
\end{tabular}


Negash Gelata and Heinrich Grausgruber

\section{Bread}

Dufo-Dabo is a popular food prepared occasionally at home during holidays (Easter, Christmas, and Baptism day), New Year and celebration of children's birthdays, social and cultural gatherings, e.g. Debo and Mabara. This type of bread is served together with Farso or coffee. In the preparation of bread, wheat flour is thoroughly mixed with water and yeast and dough is left for fermentation for some time. The bread is then baked on a heated metal pan or on a traditional clay pan called Eelee (syn. Mitad).

Budena (syn. Injera) is a main dish served with cheese, vegetables or any other spiced sauces of different sources (animals and/or plants) and it is eaten any time. To prepare such dish, wheat flour is mixed with water and yeast and left for some time for fermentation. More water is added to the dough to make it less strong. The fermented dough is used to make the flat, pancakelike bread using a metal pan or the traditional clay pan.

Households prepare Ambasha (syn. Kita) frequently at breakfast and it is served with coffee or tea. Households living in urban or peripheral urban areas prepare Ambasha for sale on the market. The preparation is similar to Budena but the dough is stronger and less fermented.

\section{Porridge}

Kinche and Marka are prepared by households usually for breakfast or dinner. For Kinche coarse wheat flour is boiled in a metal or clay pot. Usually Kinche is eaten with spiced butter (Ghee). Marka is prepared also on the occasion of child's birthday celebrations and approximately on the fifth day of newborn child (Gaafa shananii). Women in the village gather at the house of the newborn child and eat Marka together with spiced butter. For the mother Marka is believed to be a source of energy. Marka is prepared from coarse wheat flour mixed with some maize flour. The mixture is added to hot water in a metal or clay pot and mixed thoroughly. While stirring the suspension continuously it is heated until it is ready to eat. Maize flour is added in order to improve the colour of the food. Marka is served with spiced butter and cheese.

\section{Boiled and Roasted Whole Grain}

Mullu and Aka'i are snacks usually prepared and eaten any time at home but particularly during coffee drinking. In rural communities of West Shewa daily coffee drinking is important for the communication within villages. All households of one and the same village gather in one house. The meeting place of the household is rotating every day so that every household has the opportunity to prepare coffee for the residents. This is on voluntarily basis and not obligatory and has social, cultural, political and economic implications. During the time of coffee drinking people exchange their views on social, political, economic and cultural aspects. Mullu and Aka'i are also prepared for children who look after the animals in rural areas. These two snacks are more palatable and more nutritious when mixed and eaten with legumes such as faba beans, field peas or chickpeas. Usually Mullu and Aka'i are not considered as main dishes but as supplement to other diets. Both are eaten at any time.
Sci. Technol. Arts Res. J., Oct-Dec 2013, 2(4): 62-70

For the preparation of Aka'i wheat grains are mixed with legumes and socked with salted warm water for some time. Then the mixture is roasted on traditional clay or metal pan. The proportion of added legumes is less than that of wheat grain. Salt is added to the mixture for taste. For Mullu the wheat grain/legume mixture is boiled in metal or clay pot.

\section{Other Flour Products}

Dabo-kolo and biscuits are prepared occasionally at home during holidays or some other special gatherings. Both can be prepared and eaten during holidays and religious and social ceremonies. These products are also taken by persons who are travelling long distances since they can be used as snacks and stay for long time without deterioration. The dough is prepared similar as for Ambasha. Sugar is added to make it sweet. The partially fermented dough is made to a thin rod-like shape and cut into smaller pieces. Then it is roasted on heated clay or metal pan.

\section{Malt and Beverages}

Homemade beverages are prepared from Bikil (malt). Wheat grains are soaked in water and left overnight. The next day the grains are separated from the water and put in airtight containers in a dark place for approximately 4 to 6 days. The then germinated grains are dried in the sun until the moisture is reduced to approximately 7 to $10 \%$. Subsequently, the grains are milled to flour.

Farso is a homemade beer from wheat grain alone or mixed with other cereals such as maize, barley, sorghum, tef or finger millet. Landraces with purple/black grains are preferred by brewers and consumers. Beer made from these varieties is believed to be strong and best in quality. Farso is drunk at any time, however, it is more available at households during religious (e.g. New Year, Maskal, Easter) and non-religious holidays, social gatherings (e.g. Debo and Mabara), celebrations of wedding ceremony and/or children's birthdays, etc. Often homemade Farso is sold on markets for the urban and suburban communities and, therefore, represents an important source of income. For the preparation of Farso the milled malt flour is mixed with the powder of dried leaves of Gesho (Rhamnus prinoides) and water in airtight containers. After two to three days, Asharo (roasted coarse grain flour) made from maize or sorghum is added and kept for three to four additional days in the airtight containers. Also more water is added to the mixture. The whole process takes six to ten days depending on the temperature of the surrounding area.

Arake is an alcoholic spirit made from Bikil, powder of dried Gesho leaves and water. As for Farso the mixture can contain other cereals like barley, sorghum, maize, tef or finger millet and it is kept in airtight containers. Arake preparation is more laborious than Farso. Hence, it is mostly prepared for religious and non-religious ceremonies, e.g. for the celebration of wedding in Ethiopian Orthodox Church and the traditional Oromo religion Wakefata. After two days of fermentation in the container, bread made from wheat, barley or millet flour is added and the mixture is kept for another three to five days. The solution is thicker than for Farso since not so much water is added. Finally the solution is made to spirit by the local distillation process. The alcoholic content of 


\section{Negash Gelata and Heinrich Grausgruber}

Arake is higher than for Farso. As for Farso purple grained varieties are preferred. Preparation of Arake and selling on markets is a way of income for urban and suburban women.

\section{Folktales and Proverbs}

There are many folktales, proverbs and poems related to cultivation and end use of wheat landraces (Table 5). In all Oromo communities, folktales, proverbs and poems are popular and used as direct or indirect expression to convey messages to other fellows in the community on
Sci. Technol. Arts Res. J., Oct-Dec 2013, 2(4): 62-70

different aspects, e.g. society, culture or politics. For example 'lyyolee ya qamadii Baalee, yeroo arraa fira farsoo fi arakee caala, lammii kee hin dagatiin ya Jale' is an expression used to express political displease. In this saying there are three main phrases: (1) 'Qamadii Baalee' means wheat from Bale; it is referring to the main production areas of wheat, the Bale highlands in Oromia region; (2) Farso and Arake are two alcoholic beverages prepared from wheat which most people drink; (3) 'Lammii' means nationality.

Table 5: Folk songs, proverbs and poems related to wheat cultivation in Ambo and Dandi Districts.

\begin{tabular}{|c|c|}
\hline Traditional Oromo sayings & English Translation \\
\hline 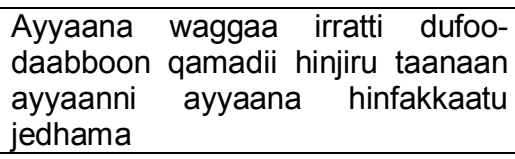 & $\begin{array}{l}\text { A holy day without serving dufo-dabo } \\
\text { is not a good looking one }\end{array}$ \\
\hline Maliif akka farso qamadii danfitaa? & $\begin{array}{l}\text { Why do you be 'hot' like beer made of } \\
\text { wheat? }\end{array}$ \\
\hline
\end{tabular}

Anati si dha'e miti barsadaaditi si dha'e

I did not hit you but basadaadi did it

Qoran hindhaqiin si irrattin beekaa, gurguradheen mana bunaatti si eegaa

Do not go collecting fire wood instead I invite you at restaurant after I sell improved wheat seed

"Lookoon lafatti na c dhittee, “ Bunee/Mariinoo ttin gala, lafa Bune/Marino where there is hunger" xanneen mite" jette qamadiin sanyii filatamaa qamadii

\section{Meaning}

For the occasion of holiday bread (dufodabo) is used as a (status) symbol

Refers to the fast fermentation of beer made of wheat and related to a person who is speaking fast.

Refers to the high alcoholic content of beer or liquor made of wheat variety barsadadi. A person who drinks a beer prepared from this variety, gets drunken and loss balance easily.

A person who is speaking to other fellow and explaining him/her the high productivity of improved wheat variety that generates high income as compared to others.

Bune and Marino are the places where there is scarcity of grain/food crops than Loko

Jibat is the place where high production of wheat in west Shewa. People of the area are giving priority for their wheat fields

A person speaking to other fellow and reminding him/her not to forget his/her when ever appointed to some position in political aspects

Appreciating one's beauty by comparing with wheat grain

Bareedaa qamadii fakkaata

Beautiful like wheat grain

Appreciating the beer quality and its strength made of purple grained wheat

Farso qamadii diimaa hindhugiin jennaan dhugde machooftee kuno ciisii urjii laka'ii

I told you not to drink beer made of purple grained wheat but you did it hence lay down and count the star

Ayyaana waggaatti dufoo -daabboo During holidays people hold bread

qamadii baatanii waaqa kadhatu (dufoo-daabboo) made of wheat and jedhama give thanks to God
Refers to the tradition of bread serving and worshiping during holidays
In the proverbs the farmers also express aspects of cultivation and quality. Concerning end use quality several sayings are related to purple grained wheat landraces. These varieties, e.g Qamadi-Dima, are preferred for malting and brewing since the product is the strongest and best alcohol. Such specific end use quality can contribute to the on farm conservation of old, lower yielding landraces. In fact Qamadi-Dima is still grown by the highland farmers because of its distinct malting quality. Some foods, e.g. Dufo-dabo, are prepared and eaten not regularly but only for special occasions like religious holidays. Therefore, such products are often related to cultural or religious values and are often used as symbols in rituals.

\section{DISCUSSION}

The major seed sources of wheat (landraces and improved) varieties are local markets, neighbours through exchange, farm saved seeds, extension services (government or seed enterprises). There are two advantages of having seeds locally: First, it conserves the indigenous knowledge together with the landraces. The 


\section{Negash Gelata and Heinrich Grausgruber}

second, it is a low cost production processes and is being accessible to all community members. Seed selection is done twice per season. The first is at planting. During planting farmers use clean and pure seeds through different means. This is done by cleaning and avoiding inert, weed seeds and other seeds of other crops or same crop of different varieties if the two varieties are easy to different. The second is selection of seeds during harvesting. Farmers select heads of good looking, healthy, and disease free materials every season. By doing these, it is possible to increase the yield of the varieties and these practices in modern term is called "mass selection" which is useful in self pollinated crops and even it works for cross pollinated crops like maize, sorghum etc. The other advantages of these activities are farmers are maintaining the diversities of their crops while they are familiar with characteristics of their varieties. The major grain storage structures are Gumbi, Gagura and Qalqalo. Gotara and Gani are less frequently used. However, Mendesil et al. (2007) reported that among the grain sorghum storage structures available, Gotera $(81 \%)$ is predominantly used by the communities and followed by sacks $(17 \%)$ in south western Ethiopia.

In the present study nine diverse foods and two beverages were described to be made from tetraploid wheat landraces at farmers' households in Ambo and Dandi districts of West Shewa. Similarly, Tsegaye and Berg (2007b) reported 14 foods and two beverages from durum wheat landraces in East Shewa. Most of the reported dishes and drinks are similar with those of the present study (e.g. Dufo-dabo, budena/injera, kinche, mullu/nifro, marka/genfo, ambasha/kita, dabo-kolo, biscuit and farso/tela and arake/arekie). Some foods, however, are particular to East Shewa (e.g. Anebabero, chuko, chechebsa, mulmul and gulban). Tsegaye and Berg (2007a) reported 26 durum wheat landraces once grown by the farmers in East Shewa. In West Shewa, 20 landraces were grown by the farmers (Geleta and Grausgruber, 2013a). Some of the landraces reported by the authors for East Shewa were also found in West Shewa (e.g. Hayibo, boyido, butuji/bataja and galane). It can be assumed that many of landraces reported by Tsegaye and Berg (2007a) might be similar with one reported by Geleta and Grausgruber (2013a). Landraces are named by local language. Tsegaye and Berg (2007a, b) reported Amharic names (local names) of the landraces and their end products. On the other hand, the present investigation was carried out in rural areas of West Shewa where people speak only the Oromo language. Therefore, same landraces might have been reported by different names of different languages. Eticha et al. (2009; 2010) reported 17 different kinds of foods and beverages from barley landraces in Dandi and Jeldu districts, West Shewa, Ethiopia. As Tsegaye and Berg (2007a, b) stated the number of households' end uses is directly related to the diversity of landraces on-farm. Wheat grains are more preferred than other grains by producers because of its fast and easy processing into different food and beverages (different bread types, and malt or beer/liquor). This is also demonstrated by the traditional proverb 'Why are you hot like beer from wheat' (see Table 3). Malt mixtures containing wheat during homemade beer processing ferment faster; and dough from wheat flour ferment faster than the dough from tef (Eragrostis tef (Zucc.) Trotter) flour. Moreover, it is possible to get more
Sci. Technol. Arts Res. J., Oct-Dec 2013, 2(4): 62-70

versatile homemade products from wheat as compared to other cereal crops like tef, maize (Zea mays L.) or sorghum (Sorghum bicolour (L.) Moench).

Different traditional foods/drinks are the results of many different wheat landraces. It was observed that specific landraces are best suited for homemade products. For instance, the purple grained landraces are mainly used for the preparation of alcoholic beverages while those with white/red seed colour are used for traditional foods. The type of traditional food also depends on the specific characteristics of seeds, e.g. Kinche (porridge) is prepared from landrace varieties with hard and vitreous seeds, and marka (porridge) is prepared from landrace varieties with white grains. Ethiopian landraces of tetraploid wheat can be grouped into red, purple and white seed colours and the different seed colours are used for different purposes (Tsegaye et al., 1994). Dishes prepared from purple wheat have a special taste, aroma and flavour despite their darker colour (Tsegaye and Berg, 2007b). The purple colour of seed is due to the content of anthocyanin in the pericarp (Zeven, 1991). Because of the anthocyanin content processed products from purple wheat are considered to have special health benefits. Anthocyanins are natural colorants with antioxidant activities in the human body when consumed in diets. Its known health benefits include the reduction of colon cancer (Lila, 2004; CastanedaOvando et al., 2009). Although the amount of anthocyanins is affected by processing, storage temperature, $\mathrm{pH}$ of the solution etc. certain amounts are still found in the final products. Malt and subsequently beverages are traditionally prepared from purple wheat. Belay et al. (1995) stated that in rural areas of Ethiopia arake (alcoholic liquor) from purple wheat is the most important beverage which is also used as traditional medicine in regard to digestion and stomach discomfort. It was reported by the farmers that purple type variety (e.g. Qamadi Dima, in present investigation) is very fast and uniform in germination within very short time during malt preparation. Wheat varieties which are susceptible to preharvest sprouting are fast in germination when soaked in water. In the present case farmers did not mention the problem of pre-harvest sprouting for Qamadi-Dima. Studies on the inheritance of genes for purple grains showed that there is no linkage between genes conferring purple pericarp and genes responsible for pre-harvest sprouting (Dobrovolskaya et al., 2006). It can be assumed that in Qamadi-Dima other genes are responsible for a fast and uniform germination during malting. However, this area needs further investigations. Not only its fast germination but also its quality products when used as malt in homemade breweries make it very unique. Tsegaye and Berg (2007b) also stated that households in East Shewa prefer purple wheat for malting.

Some of the traditional foods/drinks prepared from tetraploid wheat landraces are served at special occasions like holidays or social gatherings. The presence of some of the foods/drinks or their use in rituals signifies their importance in cultural and religious life of rural communities, indicating that it is a long tradition of wheat cultivation. Also many folktales and proverbs document the traditional way of agriculture and wheat cultivation. Tetraploid wheat has been under cultivation in Ethiopia for thousands of years. Thereby it has acquired a diverse set 


\section{Negash Gelata and Heinrich Grausgruber}

of characteristics that makes the country a centre of diversity for the species (Perrino and Porceddu, 1990; Vavilov, 1992; Feldman et al., 1995). However, according to Belay and Furuta (2001) T. dicoccon was the first Ethiopian tetraploid wheat to arrive in Ethiopian highlands $\sim 5000$ years ago. It is not known whether the present day free-threshing tetraploid landraces are direct descendants of $T$. dicoccon or whether they were introduced independently. Results from the experiment of Belay and Furuta (2001) favour the latter hypothesis and the presence of gene flow between free-threshing types and T. dicoccon.

For Oromo people folktales, poems, proverbs and folksongs (Geerarsa) are important socio-cultural life styles to pass their culture to the next generation. Thereby elder people teach the young people social, cultural, political and agricultural knowledge and/or manners. The findings of the present study help to document Oromo traditions in regard to wheat production and it could serve as a basis for further detailed investigations on cultural and economic situations of highland farmers of Ambo and Dandi districts of West Shewa. Moreover, the traditional knowledge of farmers based on cultural and ritual values in the region might help in case of the reintroduction of wheat landraces for on-farm conservation and thereby increase diversity on the table.

\section{CONCLUSION}

Ambo and Dandi districts of the west Shewa, Ethiopia highlands grow wheats for different end uses' qualities. Seed selection systems by farmers play a critical role in determining the purity of the variety and for further improvement the grain yield. Different traditional storage structures have been used for temporary storage of grains or seeds. The types of structures used by the communities are based on the intended use of the seeds/grains. Different wheat landraces were used for preparing different end products such as food and beverages. Seed colour plays a critical role in determining end use qualities. White seed varieties are mainly preferred for food uses while the purple seed types are mainly used for beverage production. The people of the two districts have deep rooted culture connected to wheat production. Farmers use folksongs and proverbs to express the end use qualities and their agronomic characteristics of different wheat landrace varieties.

\section{ACKNOWLEDGEMENT}

The authors are grateful to the farmers of the Ambo and Dandi Districts for the valuable information and experience they shared. The authors thank the Dandi and Ambo Agricultural Offices for their cooperation in giving secondary information. The study was financially supported by Austrian Cooperation for Higher Education and Research.

\section{REFERENCES}

Asfaw, Z. (2000). The barley of Ethiopia. In: Brush SB (Ed.) Genes in the field: on-farm conservation of crop diversity. Lewis Publishers, London, pp. 77-107.

Belay, G., Furuta, Y. (2001). Zymogram patterns of $\alpha-$ amylase isozymes in Ethiopian tetraploid wheat landraces: insight into their evolutionary history and
Sci. Technol. Arts Res. J., Oct-Dec 2013, 2(4): 62-70

evidence for gene flow. Genetic Resources and Crop Evolution 48: 507-512.

Belay, G., Tesemma, T., Bechere, E., Mitiku, D. (1995). Natural and human selection for purple-grain tetraploid wheats in the Ethiopian highlands. Genetic Resources and Crop Evolution 42: 387-391.

Bekele, E. (1984). Analysis of regional patterns of phenotypic diversity in the Ethiopian tetraploid and hexaploid wheats. Hereditas 100: 131-154.

Castaneda-Ovando, A., Pacheco-Hernandez, M.L., PaezHernandez, M.E., Rodriguez, J.A. and Galan-Vidal, C.A. (2009). Chemical studies of anthocyanins: a review. Food Chemistry 113: 859-871.

Central Statistical Authority (2012). Agricultural Sample Survey 2011/2012 (2004 E.C.), Report on Area and Production of Crops (Private Peasant Holdings, Meher Season), Vol. 1. Statistical Bulletin, Addis Ababa.

Dobrovolskaya, O., Arbuzova, V.S., Lohwasser, U., Röder, M.S., Börner, A. (2006). Microsatellite mapping of complementary genes for purple grain colour in bread wheat (Triticum aestivum L.). Euphytica 150: 355-364.

Eticha, F., Bekele, E., Belay, G., Börner, A. (2005). Phenotypic diversity in tetraploid wheats collected from Bale and Welo regions of Ethiopia. Plant Genetic Resources 3: 35-43.

Eticha, F., Belay, G., Bekele, E. (2006). Species diversity in wheat landrace populations from two regions of Ethiopia. Genetic Resources and Crop Evolution 53: 387-393.

Eticha, F., Berghofer, E., Grausgruber, H. (2009). Utilization of barley (Hordeum vulgare L.) landraces in the highlands of West Shewa, Ethiopia. Plant Genetic Resources 7: 154-162.

Eticha, F., Sinebo, W., Grausgruber, H. (2010). On-farm diversity and characterization of barley (Hordeum vulgare L.) landraces in the highlands of west Shewa, Ethiopia. Ethnobotany Research and Applications 8: 25-34.

Feldman, M., Lupton, F.G.H., Miller, T.E. (1995). Wheats. In: Smartt, J., Simmonds, N.W. (Eds.), Evolution of crop plants. Longman Scientific, London, pp. 184-192.

Geleta, M., Asfaw, Z., Bekele, E., Teshome, A. (2002). Edible oil crops and their integration with the major cereals in North Shewa and South Welo, Central Highlands of Ethiopia: an ethnobotanical perspective. Hereditas 137: 29-40.

Geleta, N., Grausgruber, H. (2012). Classifying Ethiopian tetraploid wheat (Triticum turgidum L.) landraces by combined analysis of molecular and phenotypic data. Science, Technology and Arts Research Journal 1(1): 19.

Geleta, N., Grausgruber, H. (2013a). On-Farm Diversity and Genetic Erosion of Tetraploid Wheat Landraces in Ambo and Dandi Districts, West Shewa, Ethiopia. Science, Technology and Arts Research Journal 2(1): 1-9.

Geleta, N., Grausgruber, H. (2013b). Morphological and quality traits variation in tetraploid (Triticum turgidum L.) and hexaploid (Triticum aestivum L.) wheat accessions from Ethiopia. Agricultural Science Research Journal 3: 229-236.

Geleta, N., Eticha, F., Grausgruber, H. (2009). Preservation of tetraploid wheat landraces in the west central highlands of Ethiopia. In: Splechtna, B.E. (Ed.), Proceedings of the 


\section{Negash Gelata and Heinrich Grausgruber}

International Symposium Preservation of bio-cultural diversity - a global issue. BOKU University Natural Resource Applied Life Sciences, Vienna, pp. 91-98.

Grain (2007). Sorghum: A Crop to Feed The World or to Profit The Industry? Seedling - Biodiversity, Rights and Livelihood, April Issue: 2-8. Grain, Barcelona, Spain. [Available online: http://www.grain.org/seedling files/ seed-07-04.pdf; verified 3 August 2009].

Shewayrga, H., Sopade, P. A. (2011). Ethnobotany, diverse food uses, claimed health benefits and implications on conservation of barley landraces in North Eastern Ethiopia. Journal of Ethnobiology and Ethnomedicine 7: 1-15.

Lila, M.A. (2004). Anthocyanins and human health: an in vitro investigative approach. Journal of Biomedicine and Biotechnology 5: 306-313.

Mendesil, E., Abdeta, C., Tesfaye, A., Shumeta, Z., Jifar, H. (2007). Farmers' perceptions and management practices of insect pests on stored sorghum in Southwestern Ethiopia. Crop Protection Journal 26: 1817-1825.

Perrino, P., Porceddu, E. (1990). Wheat genetic resources in Ethiopia and the Mediterranean region. In: Srivastava, J.P., Damania, A.B. (Eds.), Wheat genetic resources:
Sci. Technol. Arts Res. J., Oct-Dec 2013, 2(4): 62-70 meeting diverse needs. John Wiley and Sons, Chichester, pp. 161-178.

Rana, R.B., Garforth, C., Sthapit B, Jarvis, D. (2007). Influence of socio-economic and cultural factors in rice varietal diversity management on-farm in Nepal. Agriculture and Human Values 24: 461-472.

Tsegaye, B., Berg, T. (2007a). Genetic erosion of Ethiopian tetraploid wheat landraces in Eastern Shewa, Central Ethiopia. Genetic Resources and Crop Evolution 54: 715726.

Tsegaye, B., Berg, T. (2007b). Utilization of durum wheat landraces in East Shewa, central Ethiopia: Are home uses an incentive for on-farm conservation? Agriculture and Human Values 24: 219-230.

Tsegaye, S., Becker, H.C., Tesemma, T. (1994). Isozyme variation in Ethiopian tetraploid wheats (Triticum turgidum L.) landrace genotypes of different seed colour groups. Euphytica 75: 143-147.

Vavilov, N.I. (1992). Origin and geography of cultivated plants. Cambridge University Press, Cambridge.

Zeven, A.C. (1991). Wheats with purple and blue grain: a review. Euphytica 56: 243-258. 